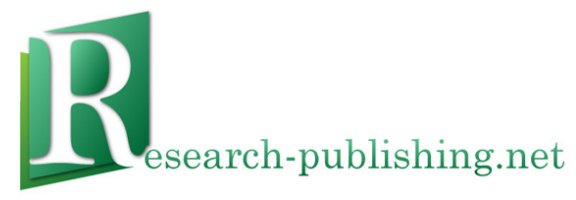

Published by Research-publishing.net

Dublin, Ireland; Voillans, France

info@research-publishing.net

(C) 2013 by Research-publishing.net

Research-publishing.net is a not-for-profit association

Case Studies of Openness in the Language Classroom

Edited by Ana Beaven, Anna Comas-Quinn and Barbara Sawhill

The moral right of the authors has been asserted

All articles in this book are licensed under a Creative Commons Attribution-Noncommercial-No Derivative Works 3.0 Unported License. You are free to share, copy, distribute and transmit the work under the following conditions:

- Attribution: You must attribute the work in the manner specified by the publisher.

- Noncommercial: You may not use this work for commercial purposes.

- No Derivative Works: You may not alter, transform, or build upon this work.

Research-publishing.net has no responsibility for the persistence or accuracy of URLs for external or third-party Internet websites referred to in this publication, and does not guarantee that any content on such websites is, or will remain, accurate or appropriate. Moreover, Research-publishing.net does not take any responsibility for the content of the pages written by the authors of this book. The authors have recognised that the work described was not published before (except in the form of an abstract or as part of a published lecture, or thesis), or that it is not under consideration for publication elsewhere. While the advice and information in this book are believed to be true and accurate on the date of its going to press, neither the authors, the editors, nor the publisher can accept any legal responsibility for any errors or omissions that may be made. The publisher makes no warranty, expressed or implied, with respect to the material contained herein.

Trademark notice: Product or corporate names may be trademarks or registered trademarks, and are used only for identification and explanation without intent to infringe.

Typeset by Research-publishing.net

Cover design: (C) Raphaël Savina (raphael@savina.net)

Fonts used are licensed under a SIL Open Font License

ISBN13: 978-1-908416-09-4 (Paperback, Print on Demand, Lulu.com)

ISBN13: 978-1-908416-10-0 (Ebook, PDF file, Open Access, Research-publishing.net)

ISBN13: 978-1-908416-11-7 (Ebook, Kindle Edition, Amazon Media EU S.à r.1.)

British Library Cataloguing-in-Publication Data.

A cataloguing record for this book is available from the British Library.

Bibliothèque Nationale de France - Dépôt légal: septembre 2013. 


\section{A Case Study into Learner Engagement in the Production of OERs within an Online Language Environment}

\section{María Dolores Iglesias Mora ${ }^{1}$ and David Elvis Leeming ${ }^{2}$}

\section{Abstract}

$\mathrm{T}$ his case study demonstrates examples of how open practices and resources can be used to effectively engage language learners in the learning process. The case focuses on a small group of Spanish Open University learners (Beginners Spanish programme - L194 Portales) that began their language course in October 2012. The case shows a successful way of using the forums as a 'portal' for distance learners to interact, create, share and cooperate in the Virtual Learning Environments, and argues how the method employed enhances the learning experience. It also illustrates how the learners actively used the target language in their interactions which then gave them confidence to build upon their language skills. Furthermore, the case study offers the reader a model to embed into their own practice, and explains the organisational considerations behind the results should practitioners choose to replicate the methodology. It concludes by postulating that OERs can offer a real opportunity to create a strong sense of learner autonomy by encouraging the learners to become engaged in the activity of creating their own authentic materials.

Keywords: open educational resources, OERs, teaching forums, online feedback, authentic materials, interactive learning, learning experience, autonomy, collaboration.

\footnotetext{
1. Open University, UK; m.d.iglesias-mora@open.ac.uk

2. University of Central Lancashire, UK; deleeming1@uclan.ac.uk
}

How to cite this chapter: Iglesias Mora, M. D., \& Leeming, D. E. (2013). A Case Study into Learner Engagement in the Production of OERs within an Online Language Environment. In A. Beaven, A. Comas-Quinn, \& B. Sawhill (Eds), Case Studies of Openness in the Language Classroom (pp. 149-161). (C) Research-publishing.net. 


\section{Context}

Open Educational Resources (OERs) have come to the fore in recent years, as the use of technology within education has flourished. Many authors, such as Hanna and Wood (2011) have observed the pedagogical benefits of the individualisation and personalisation of online learning materials. Clearly many within the educational field are acutely aware of their potential, especially as cost effective teaching resources.

Whilst the advantages seem obvious, could there be a missing link in this innovation? It is the authors' strong belief that the learner experience should be at the heart of all that we undertake as educators; indeed their professional practice is based upon this conviction. Hence a sharing community of teachers and learners, in their opinion, is the perfect arena to take this belief to another level.

It has often been observed that language learners feel most engaged when they are afforded the opportunity to focus on what is important to them, for example, the chance to talk about their family or hobbies; it gives them a sense of ownership and familiarity. It has also been observed in their teaching by the authors that there is often a desire to use authentic materials by both learners and teachers.

The authors' experiences have shown time and again the usefulness of this form of pedagogical engagement. They felt that their enthusiasm could be translated into how learners engage with the curriculum by producing, sharing and using their own authentic materials. That is, by transferring to the learners the ethos that sharing OERs is a good and productive practice, the learners would eventually understand that cooperative productive learning can make a real difference to their learning experience.

Therefore, the main purpose of the following case study will be to investigate the potential for turning leaners' production in the target language into OERs. The authors intend to, firstly, show and review the results from this relatively new angle and come up with some conclusions and suggestions for future work. 


\section{Intended outcomes}

Many within the field of education have recognised the benefits of fostering a culture of sharing work that can then be adapted and developed according to the needs of a particular teacher and group of learners. In recent years the authors have been involved in the creation and adaptation of OERs that have been uploaded and 'published openly' in LORO (Language Open Resources Online). This experience has been extremely useful, and therefore Ms Iglesias Mora (an Open University teacher) decided to experiment with this further by also engaging her students in the production of these materials.

Initially, the main goal of the project was to encourage learners to produce their own learning resources in order to consolidate their language learning. An additional goal was also to evaluate to what extent this involvement affects retention and progression of learners. At the same time, from the pedagogical point of view, the intention was to examine how this could help foster learners' autonomy and motivation as well as build a social, collaborative feeling amongst the learners. The project also explored other possible potentials of teaching forums beyond their use as simply discussion boards.

Overall, the project was initiated to increase awareness, both for teachers and learners of the benefits of incorporating Open Educational Resources into materials design and teaching by generating language learning resources and publishing them openly so that other teachers and learners could reuse and adapt them to their particular needs. Moreover, the intention was to model a collaborative learning environment (using teaching forums) as a way to introduce learners to the roles and responsibilities that learners will need to adopt should they choose to produce OERs.

\section{Nuts and bolts: Organisation}

The teacher felt that the best way of fostering this collaboration among the learners was to initially use the group forum, a teaching forum used only by 
a particular group of learners and their teacher. This was used as a 'portal' to enable learners to exchange and create their own electronic materials in the way of podcasts, short video/photo documentaries, PowerPoint presentations, and Word Documents related to the themes that learners dealt with in their course. First, the teacher posted an introductory message giving details of her expectations regarding the use of the forum and encouraging learners to participate actively. Once learners in the group got to know each other and the sense of community started to take shape, she then posted one task that gave the learners the opportunity to produce some learning material as well as practising and consolidating the language they had learnt.

Figure 1. A resource uploaded to LORO

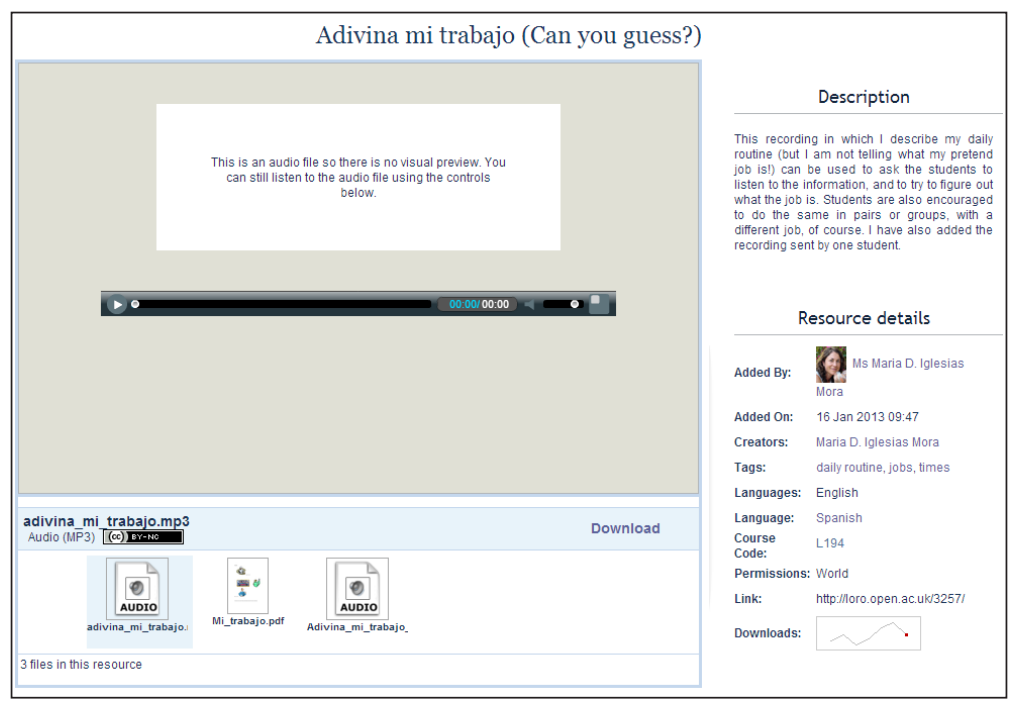

The teacher's role during this time was, first of all, to encourage and facilitate the exchange of ideas, as well as guiding in the creation of these materials. By doing this, the teacher was attempting to promote a common ground where sharing is a productive way in which learning can happen. She then edited the material sent by the learners by correcting any possible mistakes in the final version as well as giving feedback to the learners on the language they had used. 
Finally, with the learners' permission, the teacher agreed to upload the materials onto LORO, the repository of language teaching materials based at the Department of Languages at The Open University. This repository can be used by anyone, although it is mainly aimed at language teaching professionals. Figure 1 above illustrates how one of these resources has been shared openly and how it has been downloaded by other users.

\section{In practice}

In this section we present a few examples of tasks that were posted in the teaching forum, and how open educational resources were developed from them.

\subsection{Task 1 \\ "Mi familia" (My family)}

Figure 2 below shows one of the tasks posted by the teacher. In this message, the teacher is clearly initiating the creation of a collaborative learning resource by sending her own audio file with a description of her family and a family photograph. To make it a bit more challenging, some of the information in the recording does not match the photo. The idea is that the learners can listen to the recording and try to figure out what is the information that does not match the photo. Then, they are encouraged to reply by discussing the teacher's material in order to consolidate their own learning.

This is also an 'excuse' to encourage the learners to replicate, create, share and discuss their own audio files as learning resources amongst the rest of the participants of the forum.

Figure 3 below shows one of the replies. In this case, the learner has chosen to post a written paragraph (Word document) together with her own family photo. She explains that she has added four pieces of information about her family that do not match the photo. 
Figure 2. Initial posting of the task by the teacher

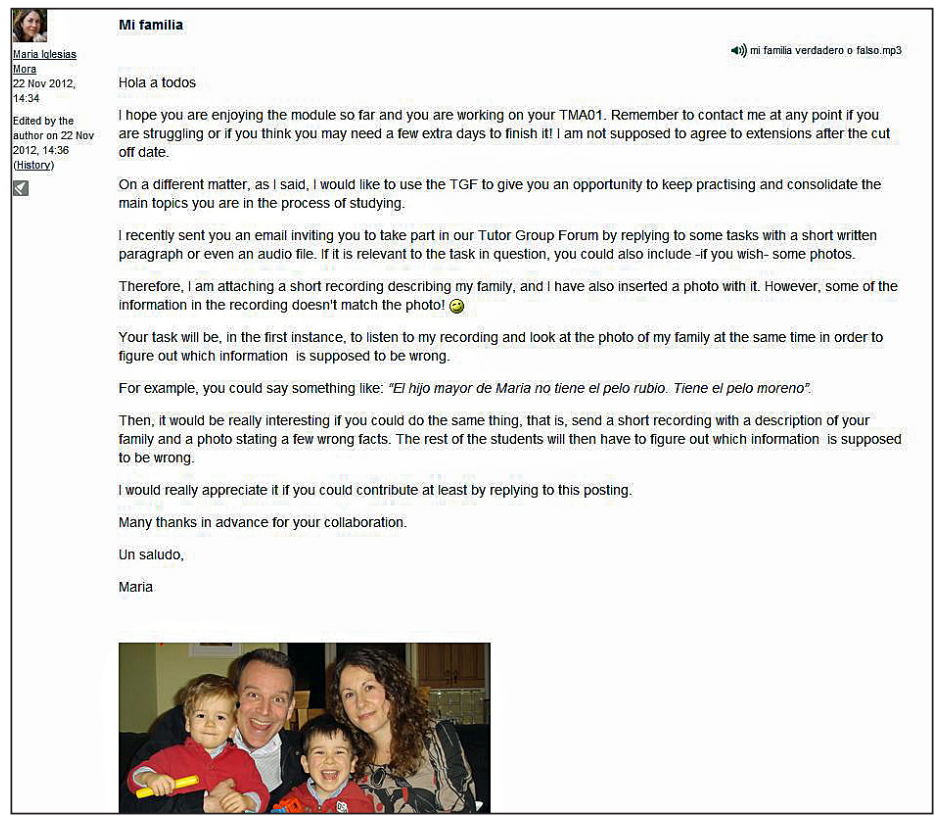

\section{Figure 3. Reply from a learner to the original teacher post}

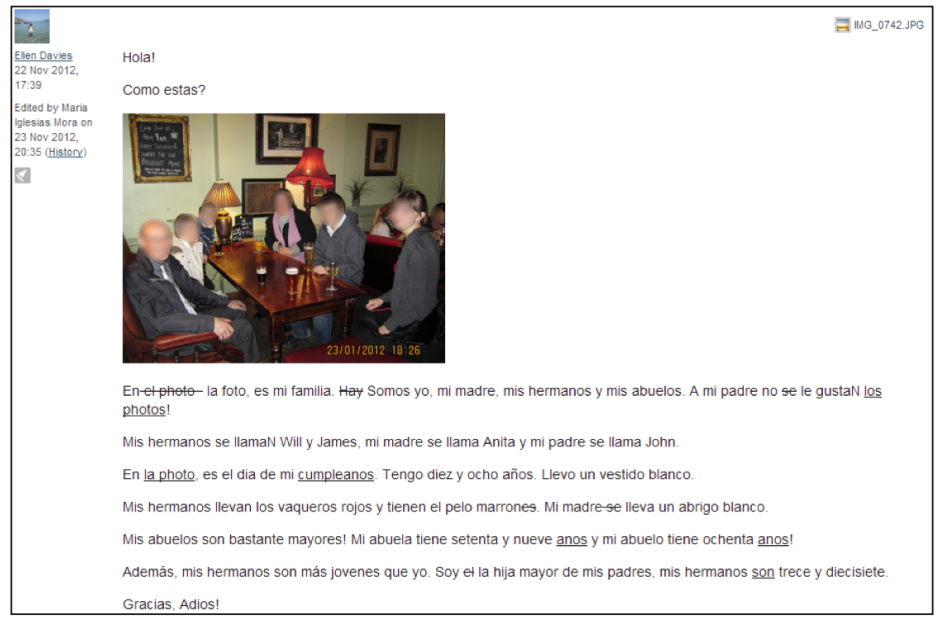


The teacher edited part of the original document to improve the presentation of the resource and to give some constructive feedback to the individual learner, which would also be of benefit to the whole group. She felt it was not necessary to correct all the mistakes the learner had made at this stage because she did not want the learner to be put off by an excessive number of corrections. Further feedback was given via email.

Following this initial posting, other learners replied to the teacher and the learner in Figure 3, pointing out the information that did not match the family photo:

Reply by RS 23 Nov 2012, 12:11: Hola a todos. ;Muy bien! Helen.

En el photo lleves un vestido negro, Will y James lleven vaqueros azules y tu madre lleve un abrigo negro. Yo mandaré un photo pronto. Un saludo

One could already see the interaction among the learners is starting to take shape.

The teacher posts other messages to give feedback to each individual learner regarding the target language used in their replies as follows:

MI (23 Nov 2012, 21:28): Hola Ellen. Well done! La descripción de tu familia es muy buena. Qué simpáticos!

Great effort. I have checked and edited a few words for you...hope you don't mind me doing it. If you prefer me to do it by email, let me know. Un saludo

ED (26 Nov 2012, 11:53): Thank you Maria, that was very helpful and $i$ can see where $i$ went wrong! Ellen

This shows how the learner is already starting to see the benefits of this collaborative work and the fact that by sharing she can also learn. Then, RS posts a recording with his description and several photos of his family (Figure 4). 
Figure 4. Reply to the original teacher post and the other learner post

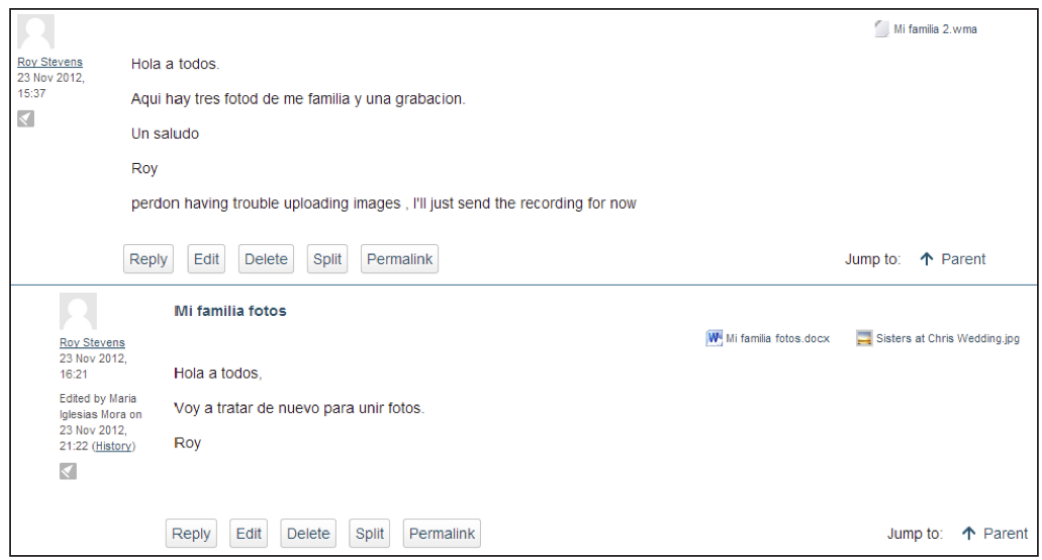

By doing this, he is attempting to follow the teacher's material and to personalise it in order to be shared with the rest of the group. The learner is already adapting and reusing the material that the teacher and his classmate have previously posted even though he may not be overtly aware of this. The teacher's job at this stage is limited to making sure she acknowledges the learners' contributions and keeping the momentum in order to facilitate the forwarding of the discussion. She only participates to encourage contribution from the other learners in the group as well as giving feedback and editing the postings whenever is necessary.

The text above shows how the interaction among two of the learners in the group is beginning to show its benefits. Their roles are starting to become more proactive as they engage in the adaptation and sharing of their materials. That is to say, they take the initiative to comment on each others' materials as well as using these to benefit their own learning. We feel at this stage the learners could probably post their ideas as a way of practising the target language but they do not necessarily understand they are starting to develop new skills to share and collaborate openly.

It is important that the teacher introduce them to this new role in a progressive way in order to make them aware of the benefits of moving from being just 
passive recipients to becoming active participants in the learning process that will culminate in the sharing and creation of OERs. This highlights that teacher facilitation, guidance and support are essential and needed throughout the whole process.

We can see that throughout this process, the learners take the initiative to generate their own materials in order to be posted in the teaching forum, whilst the teacher only participates to encourage contributions from the other learners in the group as well as giving feedback and editing the postings whenever is necessary.

With the learners' permission, these resources could be polished and uploaded to LORO for other teachers and learners to use or reuse. By guiding learners to eventually have their materials published as OERs we are also giving them an incentive to increase their motivation and consolidate their own learning by being more focused on producing quality work that they know would be shared with the community. This certainly seemed to be an incentive for the learners to spend the extra time not only to produce materials, but materials they would be happy for others to view and comment on or add to.

As an extra benefit to the learner, we also believe this process helps instil a feeling of ownership in the learners. The learners have fed back that they felt a feeling of 'pride' by sharing their work with others, and that collaboration gives them a sense of being part of a wider community rather than an isolated learner. Arguably the skills gained from experiences like this go beyond the language and deepen their skill set in other ways from communicating ideas, presenting their work online, to critically and analytically thinking and reflecting on the comments they make and the comments made about their work.

\subsection{Task 2}

\section{"Adivina mi trabajo" (Guess my job)}

Figure 5, Figure 6 and Figure 7 illustrate another example of a forum task that leads to the creation of an OER to be shared outside the course. 
Figure 5. Initial posting of the task by the teacher

\begin{tabular}{|c|c|}
\hline \multirow{7}{*}{ 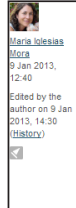 } & \multirow[t]{2}{*}{ 4)) advina mi trabsjo mp3 } \\
\hline & \\
\hline & I hope you had a nice break. \\
\hline & I am sending you a recording where I describe my dally routine (but I am not telling you what my pretend job is!). \\
\hline & With this information, you should try to figure out what my job is. \\
\hline & If you feel Ike it, you can give it a try and do the same, with a difterent $\mid 00$, of course. \\
\hline & Can you guess? \\
\hline
\end{tabular}

Figure 6. A learner's reply to the teacher posting

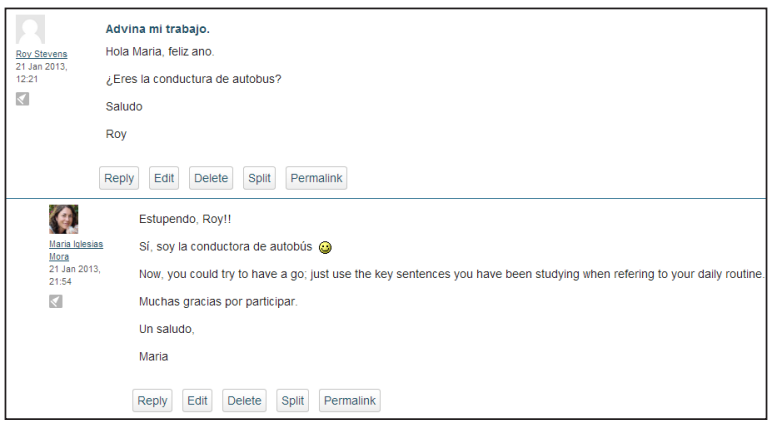

Figure 7. Learner's posting with audio resource and teacher's feedback audio file

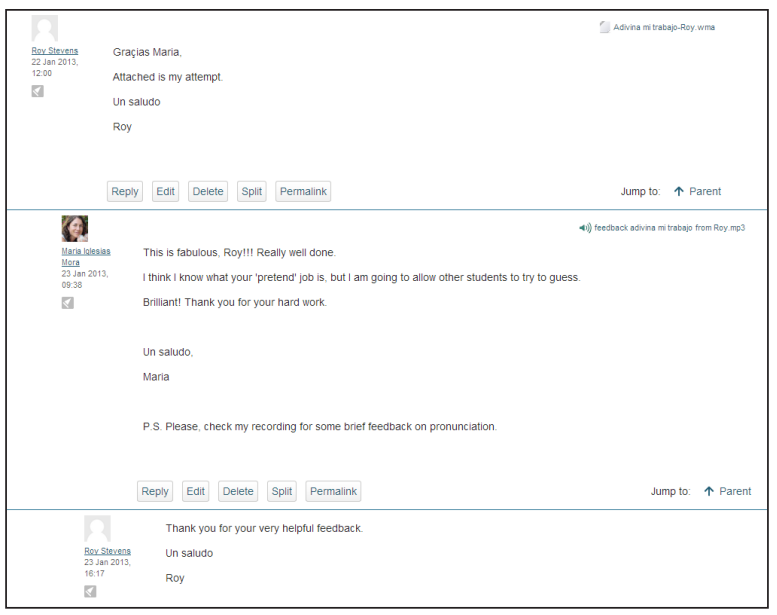


The teacher finally asks for permission to publish the material onto LORO:

MI:( 4 Feb 2013, 10:24) Hola Roy. I was wondering if you could record your message again bearing in mind my feedback.

If possible, and with your permission, I would like to incorporate and publish your work together with my recording in LORO. I think it's very good. Please, let me know what you think. Un saludo. P.S Any guesses about Roy's "mystery" job? Would anyone like to give it a try?

The above sequence shows one particular example of a learning resource that was successfully created by one of the learners and then uploaded onto LORO so that other teachers and learners can access it. The material includes audio files produced by both the teacher and the learner.

However, we consider it is equally crucial to introduce the learners to the OER 'environment' in the first instance so that they can have a better understanding of the implications of what would happen to their recordings, photos and writings. We think this could also have an impact on their motivation, since the learners know the material is going to be eventually published and shared openly with other teachers and learners.

\section{Conclusion}

In conclusion, this case study has emphasised how OERs can not only offer opportunities for learners to use their creativity in the target language, but also to produce materials that suit their interests and that are based on their personal experiences. It has also shown how the teacher's facilitation, guidance and support are needed throughout the whole process. Although the project is still ongoing, from the authors' preliminary observations one could suggest that learners seem to have gained more confidence within the very short period of time that they have been engaged in the process and have increased their collaborations and shared initiatives in the teaching forum. 
At the time this case study was written, the majority of learners in this group were still reluctant to take part in the forum and to share their ideas. This is most likely due to it being a new concept, which the learners will need to be introduced to progressively. We cannot expect the learners to grasp the concept of collaborating openly straightaway and, we believe, the degree of learners' involvement depends very much on the extent to which the teacher would model this collaborative learning environment (using the group forum in this particular case) in a positive way so that learners can see more clearly the benefits of sharing.

Given the predominance and relative importance society gives toward online social networks, this activity tries to encourage the formation of a sense of community amongst learners, who are otherwise working in isolation, at the same time that they are introduced to new roles and responsibilities they need to adopt when producing OERs in a collaborative learning environment.

If time had allowed, it would have been very interesting to have collected more in depth evidence from this fruitful experience and analysed those emails and postings from the teacher and the learners in more detail. It would also have been interesting to collect feedback about the process and results from the learners.

Nevertheless, what has been shown here are the possibilities of an open, learnercentred approach to motivate learners by offering a chance to develop learner autonomy and the sense of belonging to a shared community.

It is clear that the results are limited. However there are obvious possibilities, certainly for an online-based community. There is no doubt that this project could be easily re-purposed and tried out by practitioners in different teaching contexts and levels.

It would be very interesting to undertake the same project with Intermediate and Upper Intermediate learners of Spanish in order to compare and analyse the findings related to learners' interactions and collaboration in producing language resources. For this reason, in future, the authors' would like to carry 
out a comparative study to examine whether the level of language proficiency of learners influences the active participation in the teaching forum. They postulate that a greater linguistic ability would lead to greater participation as these learners would most likely feel more confident sharing and commenting on materials due to their higher linguistic proficiency. One could compare this to how we grow more comfortable with a language the more we understand and use it.

The authors' would also like to investigate to what extent the level of technical proficiency has an impact on the degree of sophistication of the design of the materials created by the learners. Would the use of the technical media, for example the advanced use of video diaries/journals offer more motivation for involvement than simply using text input? Of course the support of the teacher both from a linguistic and technical perspective would continue to be essential.

Acknowledgements. Many thanks to Miss Ellen Davies and Dr Roy Stevens, both Beginners' students of Spanish (L194) from October 2012. Their contributions have been invaluable both in the sessions they attended, their posts, and their collaboration for this case study.

\section{References}

Hanna, A., \& Wood, D. (2011). Bridging the gap between OER initiative objectives and OER user needs in higher education. In G. Williams, P. Statham, N. Brown \& B. Cleland (Eds.), Changing Demands, Changing Directions (pp. 539-551). Proceedings ascilite Hobart 2011. Retrieved from http://www.ascilite.org.au/conferences/hobart11/downloads/papers/ Hanna-full.pdf 